Irina Boyko, PhD, Assoc. Prof.

Zhytomyr Regional Institute of Postgraduate Pedagogical Education, Zhytomyr, Ukraine

\title{
THEORETICAL AND PRACTICAL ASPECTS OF MEASUREMENT AND EVALUATION OF INTEGRATED CHARACTERISTICS OF PROFESSIONAL COMPETENCY OF THE PEDAGOGUE
}

The article highlights the actual aspects of the interpretation of the notion of computation, competence, their use and priority directions of diagnostics of the components of professional competence of the teacher. The analysis of modern works on the competencies and competence as a multidirectional and variety of their characteristics is proved, which testifies to the very large complexity of their measurement and evaluation; an attempt was made to find ways to solve this urgent problem, which is connected with the improvement of the quality of education in the general context of its humanization. The aim is to highlight the individual professional qualities of the teacher: the general orientation of the motivational sphere, the degree of manifestation of a personal sense of professional freedom and abilities. these problems are coverage from the position of $J$. Raven and his emphasis on motivation and values of the individual. The role of the acmeological orientation of the individual is emphasized as an important factor in achieving pedagogical success. The acmeological orientation acts as a personal potential, which is a component of the individual psychological characteristics of the individual. The concept of personal potential has been developed in his works by $D$.O. Leontev and is interpreted as the ability of the individual to maintain the stability of activity under the influence of external conditions. An attempt has been made to gauge their specificity more deeply with the help of the Rorschach method. The general tendency is highlighted concerning the peculiarities of the study of the general orientation of the motivational sphere, the degree of manifestation of the personal feeling of professional freedom and abilities, which, in our opinion, is that it is relatively autonomous and its meaning lies in the field of determining the state and trends of the functioning of professional freedom, in general. Further searches are seen in solving the problem of developing effective methods for the professional diagnosis of the competence of educators in education and the creation of a continuous experimental system, which learns on the basis of own samples and errors, corrects its actions and initiates the forms of activity.

Keywords: competencies, competence, orientation of the motivational sphere, professional freedom, abilities.

Ирина Бойко, канд. психол. наук, доц.

Житомирский областной институт последипломного педагогического образования, Житомир, Украина

\section{ТЕОРЕТИКО-ПРАКТИЧЕСКИЕ АСПЕКТЫ ИЗМЕРЕНИЯ И ОЦЕНИВАНИЯ ИНТЕГРАЛЬНЫХ ХАРАКТЕРИСТИК ПРОФЕССИОНАЛЬНОЙ КОМПЕТЕНТНОСТИ ПЕДАГОГА}

Освещены актуальные аспекты толкования понятия компетенции, компетентности, их использование и приоритетных направлений диагностики составляющих профессиональной компетентности педагога. Осуществлен анализ современных работ по проблеме компетенции и компетентности - многовекторность и разнообразие их характеристик свидетельствует о сложности их измерения и оценки предпринята попытка поиска путей решения этой актуальной проблемы, связанной с повышением качества образования в общем контексте ее гуманизации. Целью является освещение отдельных профессиональных качеств педагога: общей направленности мотивационной сферы, меры проявления личностного чувства профессиональной свободы и способностей. Осуществлена попытка более глубоко понять их специфичность с помощью метода Роршаха. Освещена общая тенденция особенностей исследования общей направленности мотивационной сферы, меры проявления личностного чувства профессиональной свободы и способностей, которая, по нашему мнению, заключается в том, что она относительно автономна и смысл лежит в сфере выяснения состояния и тенденций функционирования профессиональной свободы в целом. Дальнейшие поиски видим в решении вопроса разработки эффективных методов профессиональной диагностики компетентности педагогов в образовании и создании непрерывной экспериментальной системы, которая учится на основе собственных проб и ошибок, корректирует свои действия и инициирует формы активности.

Ключевые слова: компетенции, компетентность, направленность мотивационной сферы, профессиональная свобода, способности.

Bulletin of Taras Shevchenko National University of Kyiv.

Series "Psychology". № 1(10), pp. 18-21 (2019)

УДК 159.9.07:616.379-008.64

DOI: https://doi.org/10.17721/BSP.2019.1(10).4
ISSN 1728-3817

(c) Taras Shevchenko National University of Kyiv,

Publishing Center "Kyiv University", 2019

Ірина Буровська, асп. Київський національний університет імені Тараса Шевченка, Київ, Україна

\section{ПОРУШЕННЯ МОТИВАЦІЙНО-СМИСЛОВОЇ СФЕРИ У ХВОРИХ НА ЦУКРОВИЙ ДІАБЕТ}

Розглянуто психологічні дослідження, що розкривають сутність порушень мотиваційно-смислової сфери у хворих на иукровий діабет. Описано та проаналізовано основні параметри виникнення й розвитку. иукрового діабету. Визначено особливості мотиваційно-смислової сфери у хворих на цукровий діабет. Окреслено перспективи подальших розвідок.

Ключові слова: мотиваційно-смислова сфера, цукровий діабет, хвороба, порушення, соматичне захворювання.

Постановка проблеми. На сьогодні особливої актуальності набуває вивчення психологічних особливостей виникнення та перебігу цукрового діабету у зв'язку з його високим рівнем розповсюдженості, розвитком хронічної форми та інвалідизацією хворих. Розуміння захворювання як комплексу соматичних і психологічних дисфункцій $є$ основою розроблення ефективних методів підтримки хронічно хворих осіб. Тому розкриття сутності та проведення аналізу порушень мотиваційносмислової сфери у хворих на цукровий діабет набувають значної актуальності.

Аналіз останніх досліджень і публікацій. Ґрунтуючись на проведеному теоретичному аналізі сучасних досліджень, спрямованих на виявлення та опис порушень у хворих на цукровий діабет, можемо визначити такі напрями наукових розробок зазначеної проблематики: локус контролю [5]; самооцінка [8]; внутрішня картина хвороби [6] та мотиваційний компонент внутрішньої картини хвороби [16]; багатоаспектний аналіз психологічних особливостей хворих [9; 10]; динаміка мотиваційно-смислової сфери [15], тілесний досвід, взаємозв'язок тілесності та смислового аспекту особистості [2]
Невирішені раніше частини загальної проблеми. Провівши теоретичний аналіз останніх досліджень та публікацій, можемо визначити відсутність комплексних досліджень, що розкривають сутність порушень мотиваційно-смислової сфери зазначеної групи осіб як ієрархічно організованої системи цінностей, установок, переживань і мотивів. Отже, підвищений інтерес науковців до проблеми аналізу психологічних особливостей хворих на цукровий діабет і фррагментарність досліджень у визначенні окремих аспектів у межах окресленої проблематики, актуалізує необхідність проведення даного дослідження.

Mema cmammi - аналіз порушень мотиваційносмислової сфери у хворих на цукровий діабет.

Виклад основного матеріалу. Цукровий діабет становить проблему глобального рівня для будь-якої країни світу незалежно від рівня ії̈ економічного розвитку. Про це свідчать епідеміологічні дані щодо діабету, опубліковані у 2000 р. у першому Атласі діабету Міжнародної діабетичної федерації (IDF) та всіх його шести наступних виданнях. Як зазначено в Атласі, цукровий діабет слід розуміти як хворобу обміну речовин, який регулюється нервовою та ендокринною системами. Ця 
регуляція, насамперед, спрямована на підтримання нормального рівня глюкози у крові, від якого залежить надходження глюкози у мозок та інші органи [3].

Як зауважують А.В.Штрахова та Е.В.Арсланбекова, ураховуючи психологічну складову схильності до лікування, визначають особливості мотиваційносмислової сфери хворих. Саме особливості мотиваційно-смислової сфрери формують основний фрактор схильності (чи не схильності) до лікування. Вивчення особливостей внутрішньої картини хвороби осіб, хворих на цукровий діабет, зокрема її мотиваційно-смислового компоненту, є важливою властивістю у визначенні специфічних психотерапевтичних цілей [13].

Зазначимо, що мотиваційно-смислова сфера особистості, яка умовно розмежовується на два окремих структурних компоненти, є єдиним утворенням.

Для дослідження порушень у мотиваційносмисловій ссрері у хворих на цукровий діабет проаналізуємо ланки, в яких вони відбулися.

Так, мотиваційна сфрера характеризується як ієрархічна система мотивів особистості. Мотивація визначає активність особистості та детермінує її поведінку, діяльність. До складових компонентів мотивації особистості, здебільшого, відносять: мотиви, потреби, інтереси, цілі, прагнення, мотиваційні установки, ідеали. Багатозначність поняття мотивації закономірно привела до вияву різних полюсів в уявленнях про сутність мотивації. У змісті мотивації виділяють відносно стійкі параметри, чи базисні потреби, або диспозиційні, узагальнені мотиви, і відносно змінні параметри, функціональні, конкретні мотиви. А. Маслоу виділяє такі два типи мотивації: подолання дефіциту, тобто потреб, невдоволення яких "створює в організмі, так би мовити, "пустоти", які мають бути заповнені в ім'я збереження здоров'я організму ззовні", а також потяг до розвитку, чи метамотивацію, "мотивацію росту над цими основними потребами, наприклад, розвиток талантів, здібностей, творчих нахилів, природженого потенціалу" [6].

При дослідженні хворих на цукровий діабет нас зацікавив аспект внутрішньої мотивації, оскільки зовнішня мотивація вже наявна у вигляді хвороби, з якою потрібно навчитися жити.

Зупинимось на теорії А. А. Файзулаєва [14], який у мотиваційному процесі виділяє чотири етапи.

Перший етап - це виникнення і усвідомлення мотиву. Усвідомленим мотивом дослідник уважає як потреби, потяги, схильності, так і будь-які явища психічної діяльності (образ, мисль, емоція). При цьому спонукальний аспект психічного явища може і не усвідомлюватись.

Другий етап, який був названий А. А. Файзулаєвим етап "прийняття мотиву". Під цією назвою дослідник розуміє внутрішнє прийняття спонукання, тобто ідентифікація його 3 мотиваційно-смисловими конструктами особистості.

Отже, на другому етапі людина, узгоджуючись зі своїми моральними принципами, цінностями, вирішує, наскільки значуща виникла потреба, потяг, чи потрібно їх задовольняти.

Після прийняття мотиву особистістю він проходить стадії подальшого розвитку, а саме: реалізація мотиву в поведінці й діяльності; закріплення мотиву в характері людини та його перетворення у властивість особистості, тобто в деякому плані у потенційне спонукання; актуалізація потенційного спонукання (спонукальної потенції, що перебуває в рисах характеру людини) [15].

Тобто, ми можемо спостерігати таке: якщо у людини не вистачає якоїсь ланки етапу, мотив може не мати чіткої усвідомленої дії. Звідси ми маємо чітке розуміння того, що мотив може втрачати свою привабливість і мотивація, як головний психологічний фактор схильності до лікування (у нашому випадку), перестає відігравати одну із ключових ролей. Це ми і спостерігаємо у хворих на цукровий діабет.
Щодо смислової сфрери, то вона є однією з найголовніших підструктур особистості; основою цієї сфери є саме особистісний смисл (за Д. О. Леонтьєвим). Зауважимо, що смисл доцільно характеризувати як основу особистісного життєконструювання. Усвідомлення особистістю смисложиттєвих основ обумовлене спрямованістю особистості на наслідування своїх ціннісних орієнтирів. Останні ж формуються та виокремлюються під впливом соціальних, психологічних, соціокультурних та інших фракторів.

Ураховуючи багатоаспектність мотиваційно-смислової сорери особистості, зазначимо, що у змістовому плані психологічної теорії та практики доцільно розглядати і мотиви, і смисли як типові для груп, що об'єднані певною ознакою.

Багатоаспектний аналіз порушень мотиваційної сфери хворих на цукровий діабет дає змогу визначити, що психотерапія здорових людей, у першу чергу, базується на позитивному світосприйнятті та усвідомленні постійного розвитку себе як особистості. На думку А. Маслоу, якщо у людини немає мотиву до розвитку, то її можна вважати хворою [6].

Дійсно, мотиваційні порушення у хворих на цукровий діабет спричинені, у першу чергу, фрізіологічними особливостями перебігу хвороби, ускладненнями, які виникають у її результаті та руйнуванням підшлункової залози. Коли накопичується невдоволеність собою та тим, що потрібно весь час контролювати свої дії (міряти рівень глюкози, дотримуватись дієти, займатись фізичними вправами), повністю змінити життя, підпорядкувати його тим змінам, які настали з початком хвороби, руйнується не тільки спонукання до розвитку, а й звичайне бажання жити. Необхідність постійно дотримуватись здорового способу життя та слідкувати за рівнем глюкози у крові стає тягарем, і відчуття благополуччя зникає, як тільки людина розуміє, що зміни ці є незворотними.

Крім внутрішніх змін, які виникають із появою хвороби, відбувається низка соціальних трансформацій. Знижується працездатність на фоні швидкої стомлюваності та сонливості. Соціальний статус хворого змінюється. Зауважимо, що близько 30 \% пацієнтів просто втрачають роботу, а $20 \%$ бояться її втратити. Тривога збільшується, збільшуються також і викиди цукру в кров. Стан хворого погіршується, самооцінка, упевненість у собі знижуються. Як правило, у такому випадку виникає замкнене коло, яке призводить до посилення виявів цукрового діабету, появи страхів та актуалізації почуття безвиході. Посилюється бажання сховатись від людей та знайти того, хто може захистити, зробити за тебе те, на що ти вже не здатний через хворобу. Інфантилізм притаманний, більшою мірою, особам із цукровим діабетом, ніж людям 3 іншими соматичними захворюваннями. Тобто, якщо у дитинстві та протягом усього свого життя людина не отримувала достатньо уваги та любові, на даному етапі вона хоче отримати це за допомогою хвороби. Вона це отримує і її це влаштовує [1].

Характерними для осіб, хворих на цукровий діабет, $€$ депресивні стани. Депресивні стани виявляються у вигляді саморуйнування на фоні особистої незатребуваності у колі сім'ї (коли хворий уважає, що отримує недостатньо уваги, "йому всі винні та зобов'язані"). Надмірна потреба в залежності та розніженості, як правило, не влаштовує партнерів [9].

Аналіз наукової літератури з теми дав змогу визначити, що вивчення цукрового діабету як психосоматичного розладу, здебільшого, проводилось і проводиться у двох напрямах, які відображають різні дослідницькі школи, які умовно можна позначити як психодинамічну та психофрізіологічну.

Зупинимось на аналізі динаміки мотиваційно-смислової сорери хворих на цукровий діабет, у межах наукових пошуків дослідників психодинамічного напряму.

Так, К. О. Меджидова, ґрунтуючись на концепції профрілю особистості F. Dunbar, зауважує: "діабетики, у 
більшому ступені, ніж люди без хронічного захворювання, змінюють свій зрілий та незалежний стан на більш інфантильний. Особам із цукровим діабетом властива тенденція швидко регресувати до залежних установок і відстоювати свої незалежні устремління, здебільшого, на словах, ніж на ділі; діабетики є більш пасивними і мають тенденцію до мазохізму і нерішучості" [7].

Зауважимо, що на думку Ф. Александера, "виникнення цукрового діабету, як і виникнення будь-якого хронічного захворювання, може викликати значні психологічні зміни у самих хворих, а також у членів їх сімей та соціальних груп, до яких вони належать. У них може бути уражене самолюбство, з'явитися страх і почуття неповноцінності, зрости потреба у турботі з боку інших людей і посилитися ворожість. Згідно з різними формами захисту, що виникають у відповідь на надмірне напруження, реакція на виникнення хвороби може значно відрізнятися і виявлятися у вигляді параноїдних, депресивних та іпохондричних симптомів. Деякі пацієнти реагують апатією, яка може бути інтерпретована як адаптивна поведінка, спрямована на збереження енергії" [1].

Звернемося до аналізу наукових розвідок А. В. Штрахової та Е. В. Арсланбекової.

У фокусі їхніх досліджень [13] - особливості мотиваційно-смислової сфери хворих на цукровий діабет. Ґрунтуючись на аналізі наукових праць із теми, авторки узагальнюють, що мотиваційну сферу слід розглядати як динамічне утворення, яке змінюється протягом життя. Мотиваційна сфера особистості служить важливим показником цілісної, гармонійної особистості та визначає поведінку людини і в ситуаціях зміни образу життя при хронічних соматичних захворюваннях. В основі мотиваційних спонукань в умовах хронічного соматичного захворювання, за А. В. Штраховою та Е. В. Арсланбековою, знаходяться цінності особистості.

Емпіричне дослідження мотиваційно-смислової сфери осіб, хворих на цукровий діабет, проведене А. В. Штраховою та Е. В. Арсланбековою, дало змогу визначити, що в основі прихильності до лікування соматично хворих осіб - особливості мотивації, що формують детермінанту такої схильності або ії̈ відсутність. Активна мотивована діяльність хворих на цукровий діабет у ситуаціях, що мають стосунок до їх здоров'я, свідчить про прихильність до лікування [13].

Таким чином, А. В. Штрахова та Е. В. Арсланбекова у дослідженнях, присвячених виявленню порушень мотиваційно-смислової сфери хворих на цукровий діабет, визначають активну мотивовану діяльність із підтримки та покращення свого здоров'я як спосіб подолання ситуації вітальної загрози.

Виникає питання, як допомогти хворому, у якого цінність особистого життя зовсім невелика? Наше завдання - розглянути, в якій саме ланці втрачається мотивація та як можна знайти сенс для відтворення бажання жити і спробувати "домовитись із хворобою", а не повністю в неї зануритись.

Н. Пезешкян [11], засновник позитивної психотерапії, однією з ланок виходу із хвороби вважає "фантазію або майбутнє". Тобто, якщо починати позитивно сприймати майбутнє і налаштовуватись на період часу, який буде існувати завжди, пацієнт починає шукати мотивацію саме для подовження життя як такого. Сенс життя починає зростати і вмотивованість до змін приходить хоча б тому, що віра у позитивні зміни стає просто потребою.

Т. Д. Василенко [2] фокусується у своїх дослідженнях на вивченні смислових аспектів тілесного досвіду соматично хворих із хронічним перебігом захворювання на прикладі осіб, хворих на цукровий діабет. Науковцями було виявлено, що тілесний досвід хворих на цукровий діабет пов'язаний зі змінами смислової сфери. Зміни смислової сфери осіб, хворих на цукровий діабет, виявляються в переважанні негативних оцінок щодо подій минулого, сьогодення та майбутнього й нівелюванні значущості раніше пріоритетних життєвих цілей.

Т. Д. Василенко [2] зі співавторами встановили переважання у групі досліджуваних осіб, хворих на цукровий діабет, уявлень про себе як про особистість, що не здатна контролювати своє життя повною мірою, відповідно до цілей та уявлень про сенсожиттєві основи конструювання свого майбутнього. Дослідження тілесного досвіду хворих дало змогу визначити сприймання досліджуваними власного тіла як перешкоди. Специфічні симптоми захворювання спричинили інтеграцію тілесного досвіду в Я-структуру, сприяючи формуванню сприйняття свого тіла більшою мірою як біологічного фрактора. Блокування рефлексивних процесів та підвищення екстерналізації рівня локусу контролю обумовлюють дезадаптивний взаємозв'язок тілесності та смислового аспекту особистості.

Висновки 3 даного дослідження. Отже, аналіз психологічних досліджень порушень мотиваційносмислової ссрери хворих на цукровий діабет дозволив описати ланки мотивації у хворих на цукровий діабет і можливі сфери порушень у них; визначити психологічні порушення, пов'язані саме із хворобою та важливу роль тілесності у блокуванні смислового аспекту осіб, хворих на цукровий діабет.

Вивчення напрямів досліджень розкриває можливості позитивної психотерапії та її ролі у мотиваційно-смисловій сфері для хворих на цукровий діабет. Аналіз праць із окресленої проблематики показав необхідність проведення комплексних досліджень у даному проблемному полі.

Перспективи подальших розвідок. Перспективами подальших досліджень $є$ розробка моделі мотиваційно-смислової сорери осіб у хворих на цукровий діабет; підбір психодіагностичних методик з метою проведення подальшого емпіричного дослідження, спрямованого на вивчення мотиваційно-смислової специфіки осіб, хворих на цукровий діабет.

Список використаних джерел

1. Александер Ф. Психосоматическая медицина / Ф. Александер пер. с англ. А. М. Боковиков, В. В. Старовойтов. - 2018. - 382 с.

2. Василенко Т.Д. Смысловые аспекты телесного опыта хронического соматического заболевания / Т.Д. Василенко, А. В. Селин, Ф. Ю. Мангушев// Курский науч.-практ. вестн. "Человек и его здоровье". - 2016. № 2. - С. 116-121.

3. Диабетический атлас [Электронный ресурс] // Режим доступа: https://docplayer.ru/33391186-Mezhdunarodnaya-federaciya-diabetadiabeticheskiy-atlas.html.

4. Качан Е. П. Особенности внутренней картины болезни у пациентов с сахарным диабетом 2-го типа в зависимости от длительности заболевания / Е. П. Качан, А. И. Кулак // Журн. Белорус. гос. ун-та. Философия. Психология. - 2015. - С. 108-114

5. Кирилова О. О. Новий підхід до вивчення локусу контролю здоров'я в підлітків із цукровим діабетом I типу / О. О. Кирилова // Укра. журн. дитячої ендокринології. - 2017. - № 1. - С. 16-20.

6. Маслоу А. Мотивация и личность / А. Маслоу ; пер. с англ. - 1970. - 217 с.

7. Меджидова К. О. Мотивация как предмет научных исследований // Психология и Психотехника. - 2012. - № 4. - С. 44-50.

8. Меллина Т. В. Психосоматические аспекты развития сахарного диабета / Т. В. Меллина, Д. Н. Поберей. - 2012. - № 1. - С. 105-108. Код доступу: http://www.irbis-nbuv.gov.ua/cgi-bin/irbis_nbuv/cgiirbis_64.exe.

9. Менделевич В. Д. Сахарный диабет / В. Д. Менделевич, С. Л. Соловьева // Неврозология и психосоматическая медицина. - М. : МЕДпрессинформ, 2002. - С. 561-568.

10. Никоненко Ю. К. Клінічна психологія: навч. посіб. / Ю. П. Никоненко. - К. : КНТ, 2016. - 368 с.

11. Пезешкиан Н. Мне ясно, как справиться с диабетом / Н. Пезешкиан. - М. : ДиаНовости, 2003. - 223 с.

12. Прокопенко О.В. Поведінка споживачів: навч. посіб./ О.В. Прокопенко, М. Ю. Троян. - К. : Центр учбової літератури, 2008. - 176 с.

13. Штрахова А. В. Мотивационный компонент внутренней картины болезни как фактор приверженности к терапии у больных соматическими заболеваниями с витальной угрозой / А. В. Штрахова, Э. В. Арсланбекова // Вестн. ЮУрГУ. - 2011. - № 29. - С. 82-89.

14. Файзуллаев А. А. Мотивационная саморегуляция личности / А. А. Файзуллаев. - Ташкент, 1987. - 136 с.

15. Щербина Л. Ф. Динаміка смислових структур осіб, залежних від психоактивних речовин, у процесі психологічної реабілітації : автореф. дис. ... канд. психол. наук: спец. 19.00.04 "Медична психологія" / Л. Ф. Щербина. - К., 2004. - 18 с.

16. Lustman P. J. Depression in diabetic patients: the relationship between mood and glycemic control/P. J. Lustman // J. of Diabetes Complications. - 2005. - Vol. 19. - P. 113-122 
References

1. Alexander F. Psikhosomaticheskaya medicina/ F. Alexander [per. s angl. A. M. Bokovikov, V. V. Starovoytov]. $-2018 .-382 \mathrm{~s}$.

2. Vasilenko T. D. Smyslovye aspekty telesnogo opyta chronicheskogo somaticheskogo zabolevaniia /T. D. Vasilenko, A. V. Selin, F. lu. Mangushev // Kurskii nauchno-practicheskiy vestnik "Chelovek i ego zdorovie". - 2016. - № 2. -S. 116-121.

3. Diabeticheskiy atlas [Electronny resurs] //Sposib dostupu: https://docplayer.ru/33391186-Mezhdunarodnaya-federaciya-diabetadiabeticheskiy-atlas.htm

4. Kachan E.P. Osobennosti vnutrennei kartiny bolezni u patsientov $s$ sakharnym diabetom 2-go tipa $v$ zavisimosti ot dlitelnosti zabolevaniia / E. P. Kachan, $\quad$ A. I. Kulak // Zhurnal Belorusskogo gosudarstvennogo universiteta. Filosofia. Psikhologia. - 2015. - S. 108-114.

5. Kyrylova O. O. Novyi pidkhid do vyvchennia lokusu kontroliu zdorovia v pidlitkiv iz tsukrovym diabetom I typu / O. O. Kyrylova // Ukrainskyi zhurnal dytiachoi endokrynologii. - 2017. - № 1. - S. 16-20.

6. Maslow A. Motivacia i lichnost / A. Maslow [per. s angl.]. - 1970. - $217 \mathrm{~s}$

7. Medzhydova K. O. Motivacia kak predmet nauchnych issledovanii // Psikhologia i Psikhotekhnika. - 2012. - № 4. - S. 44-50.

8. Mellina T. V. Psikhosomaticheskie aspekty razvitiya sakharnogo diabeta / D. N. Poberei // Ukrainskii naukovo-medychnyi molodizhnyi zhurnal. - 2012. - № 1. - S. 105-108.
9. Mendelevich V. D. Sakharnyi diabet / V. D. Mendelevich, S. L. Soloviova // Nevrozologia i psikhosomaticheskaya medicina - M. : MEDpress-inform, 2002 S. $561-568$

10. Nikonenko lu. P. Klinichna psykhologiya: navch. posib. / lu. P. Nikonenko. - K. : KNT, 2016. - $368 \mathrm{~s}$.

11. Pezeshkian N. Mne yasno kak spravitsya s diabetom/ N. Pezeshkian. - M. : DiaNovosti, 2003. - 223 s.

12. Prokopenko O. V. Povedinka spozhyvachiv: navch. pos./ O. V. Prokopenko, M. lu. Troayn. - K. : Centr uchbovoi literatury, 2008. - 176 s.

13. Shtrakhova A. V. Motivacionnyi component vnutrennei kartiny bolezni rfr factor priverzhennosti $k$ terapii $u$ bolnyh somaticheskimi zabolevaniyami s vitalnoi ugrozoi / A. V. Shtrakhova, E. V. Arslanbekova // Vestnik luUrGU. 2011. - № 29. - S. 82-89.

14. Faizullaev A. A. Motivacionnaya samoregulyacia lichnosti. Tashkent, 1987. - $136 \mathrm{~s}$.

15. Scherbyna L. F. Dynamika smyslovykh struktur osib, zaleznyh vid psyhoaktyvnyh rechovyn, $v$ procesi psyhologichnoi reabilitacii : avtoref. dys. kand. psyhol. nauk: spec. 19.00.04 "Medychna psyhologiya" / L. F. Scherbyna. - K., 2004. - 18 s.

16. Lustman P. J. Depression in diabetic patients: the relationship between mood and glycemic control/P. J. Lustman // J. of Diabetes Complications. - 2005. - Vol. 19. - P. 113-122

Надійшла до редколегії 18.06.19

Irina Burovska, post-graduate

Taras Shevchenko National University of Kyiv, Kyiv, Ukraine

\section{DISABILITY OF MOTIVATION-SUMMER SPHERE IN PATIENTS WITH DIABETES MELLITUS}

Psychological researches that reveal the essence of disorders of the motivational and semantic sphere in patients with diabetes mellitus are considered. Understanding the disease as a complex of somatic and psychological dysfunctions gives the opportunity to develop effective methods of support for chronically ill persons, to reveal the essence and to analyze the disorders of the motivational and semantic sphere in this group of persons. Particular attention is paid to the study of the aspect of intrinsic motivation, as extrinsic motivation is already present in the form of a disease with which one must learn to live. The stages of intrinsic motivation in patients with diabetes mellitus are examined in detail, the disorders that occur on each of them are identified and analyzed. The peculiarities of patients' motivational and semantic sphere as one of the most important personality substructures have been determined. The semantic sphere of personality and the basis of personal meaning (by $D$. $O$. Leontiev) are considered. The main directions of the study of diabetes as a psychosomatic disorder are described and analyzed, which makes it possible to search for harmonious adaptation of the patient in society and individual motives for leaving the disease. The analysis of the dynamics of the motivational - semantic sphere in patients with diabetes mellitus was carried out within the framework of scientific search of psychodynamic researchers, which gives an opportunity to understand the disease as a complex of somatic and psychological dysfunctions. Possibilities of positive psychotherapy and its role in the motivational and semantic sphere for patients with diabetes mellitus are considered. The focus of our view on psychological disorders is related to illness and the important role of physicality in blocking the semantic aspect in this category of patients. The prospects for further exploration and the need for comprehensive research in this problem area.

Keywords: motivational-semantic sphere, diabetes mellitus, disease, disorders, somatic disease.

Ирина Буровская , асп.

Киевский национальный университет имени Тараса Шевченко, Киев, Украина

\section{НАРУШЕНИЕ МОТИВАЦИОННО-СМЫСЛОВОЙ СФЕРЫ У БОЛЬНЫХ САХАРНЫМ ДИАБЕТОМ}

Рассмотрены психологические исследования, раскрывающие сущность нарушений мотивационно-смысловой сферы у больных сахарным диабетом. Описаны и проанализированы основные параметры возникновения и развития сахарного диабета. Определены особенности мотивационно-смысловой сферы у больных сахарным диабетом. Определены перспективы дальнейших исследований.

Ключевые слова: мотивационно-смысловая сфера, сахарный диабет, болезнь, нарушения, соматическое заболевание.

Bulletin of Taras Shevchenko National University of Kyiv. Series "Psychology". № 1(10), pp. 21-24 (2019)

УДК 159.9.92:364.636-053.6

DOI: https://doi.org/10.17721/BSP.2019.1(10).5
ISSN 1728-3817

(C) Taras Shevchenko National University of Kyiv,

Publishing Center "Kyiv University", 2019

Марина Величко, асп. Хмельницький національний університет, Хмельницький, Україна

\section{ПСИХОЛОГІЧНИЙ ЗМІСТ ТА ОСНОВНІ ПРИЧИНИ ВИНИКНЕННЯ МОБІНГУ СЕРЕД ДІТЕЙ СЕРЕДНЬОГО ШКІЛЬНОГО ВІКУ}

Метою статті є аналіз проблеми виникнення мобінгу серед дітей підліткового віку та встановлення сутності причини його виникнення у шкільному середовищі, основних характеристик поняття, а також пошуку шляхів запобігання мобінгу.

Ключові слова: мобінг, шкільне середовище, агресор, жертва.

Тема мобінгу серед дітей дедалі частіше опиняється в центрі уваги громадськості й наукових дискусій. Про насильство в школі та дитячих садках відомо давно. Починаючи із 1905 р., у пресі почали з'являтися перші роботи, присвячені цій проблемі, пік яких припав на кінець 1940-х рр. Сьогодні проблема шкільного насилля хвилює весь світ. Так, за даними Національної асоціації шкільних психологів США, щодня понад 160 тис. школярів пропускають заняття, побоюючись стати жертвою агресії [8].

Проблема мобінгу як педагогічна була окреслена ще у 1960-1980 рр. у Швеції, потім у Німеччині, Польщі та інших країнах Європи [3].
Термін "мобінг" $є$ доволі поширеним у літературних джерелах, особливо у зарубіжних виданнях, працях із соціології та психології. Це поняття ввів у 1963 р. К. Лоренц. Він називав мобінгом феномен групового нападу декількох дрібних тварин на більшого противника. Термін у сучасному розумінні вперше використав на початку 1980-х рр. учениймедик Г. Лейман. Він провів дослідження на робочих місцях у Швеції та оцінив кількість жертв мобінгу в країні$3,5 \%$ від усього населення й охарактеризував його як психологічний терор, що включає систематично повторюване й неетичне поводження однієї або декількох осіб, спрямоване проти іншої людини [4]. 